\title{
PENINGKATAN KEMAMPUAN BERFIKIR KRITIS MAHASISWA MELALUI PENDEKATAN 5E DAN SETS BERBANTU APLIKASI MEDIA SOSIAL
}

\author{
Abdul Ghofur, Nahdia Rupawanti Basuki Raharjo \\ STKIP PGRI Lamongan, Indonesia \\ Email: ghofurkita@yahoo.com
}

\begin{abstract}
ABSTRAK
Penelitian ini bertujuan untuk menguji pengaruh pendekatan pembelajarn 5E (Engage, Explore, Explain, Elaborate, dan Evaluate) dan pendekatan pembelajaran SETS (Science, Environment, Technology, and Society) berbantu aplikasi media sosial terhadap kemampuan berfikir mahasiswa. Rancangan penelitian ini adalah desain eksperimen semu terhadap 58 mahasiswa Universitas Islam Lamongan yang dipilih dengan teknik purposive sampling. Teknik pengumpulan data menggunakan tes tulis dalam bentuk pretest dan posttest, analisis data menggunakan ANOVA dua jalur. Hasil analisis data menunjukkan bahwa ada pengaruh yang signifikan antara kelompok mahasiswa yang dibelajarkan dengan pendekatan $5 \mathrm{E}$ dan pendekatan SETS terhadap kemampuan berfikir kritis mereka. Hal ini didasarkan pada nilai F hitung sebesar 17.547 dengan nilai signifikansi sebesar 0.000. Berdasarkan hasil analisis deskriptif menunjukkan bahwa nilai rata-rata kemampuan berfikir kritis mahasiswa yang dibelajarkan dengan pendekatan $5 \mathrm{E}$ lebih tinggi jika dibandingkan dengan nilai rata-rata mahasiswa yang dibelajarkan dengan pendekatan SETS. Nilai rata-rata kemampuan berfikir kritis mahasiswa yang diberikan pembelajaran dengan menggunakan pendekatan $5 \mathrm{E}$ adalah sebesar 73.11, sedangkan nilai rata-rata kemampuan berfikir kritis mahasiswa yang diberikan pembelajaran dengan pendekatan SETS adalah sebesar 61.90.Penggunaan aplikasi media sosial pada kedua pendekatan tersebut sangat membantu melengkapi pengalaman belajar menjadi lebih konkrit sehingga dapat membantu mahasiswa dalam berdiskusi, membaca, dan praktik.
\end{abstract}

Kata Kunci: 5E, SETS, Media Sosial, Berfikir Kritis

\section{ABSTRACT}

This research aims to examine the effect of 5E learning approaches (Engage, Explore, Explain, Elaborate, and Eva luate) and SETS learning approaches (Science, Environment, Technology, and Society) assisted by social media applications on students' thinking skills. The design of this research was a quasi-experimental design on 58 Lamongan Islamic University students who were selected by using purposive sampling technique. Data collection techniques is implemented by using written tests in the form of pretest and posttest, the data analysis is conducted by using two-way ANOVA. The results of data analysis showed that there was a significant influence between groups of students who were taught with the $5 \mathrm{E}$ approach and the SETS approach to their critical thinking skills. This is based on the calculated $\mathrm{F}$ value of 17,547 with a significance value of 0,000 . Based on the results of the descriptive analysis showed that the average value of students' critical thinking skills that were taught with the 5E approach was higher compared to the average score of students who were taught by the SETS approach. The average value of critical thinking ability of students who are given learning by using the $5 \mathrm{E}$ approach is 73.11 , while the average value of critical thinking ability of students who are given learning by using the SETS approach is 61.90 . The use of social media applications in these two approaches is helpful to complete the experience of learning in becoming more concrete so it can help the students in discussion, reading, and practice.

Keywords: 5E, SETS, Social Media, Critical Thinking 


\section{PENDAHULUAN}

Berbagai kajian menunjukkan bahwa kemampuan berfikir kritis mahasiswa Indonesia masih tergolong rendah (Pradana, dkk. 2016; Putra \& Sudarti, 2015; Gunawan \& Liliasari, 2012; Mayadiana, 2005). Padahal menurut Hastuti (2013) kemampuan berfikir kritis menjadi tuntutan abad 21 yang harus dimiliki. Hal tersebut juga yang sampaikan oleh Ibrahim (2007) bahwa fokus keterampilan abad 21 diarahkan untuk meningkatkan mutu dan daya saing sumber daya manusia. Kemampuan berpikir merupakan salah satu modal yang harus dimiliki peserta didik sebagai bekal dalam menghadapi perkembangan ilmu pengetahuan dan teknologi di abad 21 tersebut, sebab keberhasilan seseorang bergantung pada kemampuan berpikirnya terutama dalam memecahkan masalah kehidupan yang dihadapinya. Selain itu, kemampuan berpikir juga sebagai sarana untuk mencapai tujuan pendidikan yaitu agar peserta didik mampu memecahkan masalah taraf tingkat tinggi (Nasution, 2008). Adapun menurut $\mathrm{Ku}$, dkk (2014), kemampuan berfikir kritis merupakan hal yang sangat penting untuk ditingkatkan, sehingga dalam beberapa hal menjadi fokus pembelajaran.

Berfikir kritis di kalangan mahasiswa merupakan sebuah hal yang sangat penting, sebab mahasiswa diharuskan untuk melakukan banyak kajian yang diharapkan bisa lebih dari sekedar belajar secara tekstual. Tingkat kemampuan berfikir kritis mahasiswa menjadi salah satu tolok ukur bagaimana yang bersangkutan dalam setiap aktivitas pembelajarannya. Sebab, dalam pembelajaran di lingkungan perguruan tinggi lebih banyak menggunakan metode pembelajaran untuk orang dewasa atau lebih sering dikenal dengan istilah andragogi. Mahasiswa yang sudah tergolong orang dewasa tentu akan lebih banyak menggunakan kemampuan berfikir kritisnya dalam setiap pengambilan keputusan. Oleh karena itu, di Indonesia kemampuan berfikir kritis mahasiswa merupakan salah satu tujuan pendidikan di perguruan tinggi. Hal ini sebagaimana tercantum dalam Undang-undang Nomor 12 tahun 2012 tentang pendidikan tinggi.

Pentingnya kemampuan berfikir kritis menyebabkan pengkajian tentang kemampuan berfikir kritis banyak dilakukan. Kemampuan berfikir kritis penting karena mahasiswa yang memiliki kemampuan berfikir kritis yang baik akan dapat menjadi konsumen sains yang kritis (National Research Council, 2012) sehingga mereka dapat mengikuti perkembangan ilmu pengetahuan dan teknologi yang setiap saat yang selalu berkembang (Luthvitasari, dkk., 2012). Mahasiswa juga dapat belajar mengumpulkan fakta-fakta yang dapat digunakan untuk menarik kesimpulan jika mereka memiliki kemampuan berfikir kritis yang baik (Seals, 2010).

Pencapaian kemampuan berfikir kritis mahasiswa dipengaruhi oleh banyak faktor, antara lain proses dan kondisi pembelajaran. Proses pembelajaran erat kaitannya dengan desain pembelajaran yang dilakukan oleh dosen. Apabila proses pembelajaran berlangsung dengan baik maka tujuan pembelajaran juga akan tercapai. Terdapat dua pendekatan pembelajaran yang berdasarkan beberapa kajian mampu meningkatkan kemampuan berfikir kritis, yakni pendekatan pembelajaran SETS (Science, Environment, Technology, and Society) dan pendekatan pembelajarn $5 \mathrm{E}$ 
(Engage, Explore, Explain, Elaborate, dan Evaluate). Menurut beberapa kajian, pendekatan SETS menawarkan kelebihanyaknimembentuklulusanyang memiliki kemampuan penalaran serta kekomprehensifan pemikiran ketika peserta didik dihadapkan pada suatu masalah untuk dipecahkan (Yulistiana, 2015; Binadja, 2002). Selain itu, hasil kajian beberapa ahli juga menunjukkan bahwa pendekatan pembelajaran $5 \mathrm{E}$ (Engage, Explore, Explain, Elaborate, dan Evaluate) mampu meningkatkan kemampuan berfikir kritis (Budprom, dkk., 2010; Appamaraka, dkk.2009; Santyasa, 2008).

Kedua pendekatan pembelajaran tersebut dalamimplementasinyamengacu pada teori belajar konstruktivisme. Menurut Barlia (2011) bahwa aktivitas pembelajaran berdasarkan prinsip-prinsip konstruktivisme menekankan kepada pentingnya keterlibatan peserta didik di dalam proses pembelajaran, serta pentingnya pengetahuan awal untuk konseptualisasi proses pembelajaran berikutnya. Teori belajar ini sangat sesuai dalam upaya meningkatkan kemampuan berfikir kritis peserta didik. Hal ini didasarkan pendapat Yamin (2008) bahwa kemampuan berpikir kritis merupakan salah satu keterampilan pada teori metakognitif yang dilandasi paradigma konstruktivistik.

Berdasarkan beberapa kajian tersebut, peneliti merasa perlu untuk melakukan kajian terkait ada tidaknya pengaruh Pendekatan Science, Environment, Technology, and Society (SETS) dan Pendekatan Engage, Explore, Explain, Elaborate, dan Evaluate (5E) berbantu aplikasi media sosial terhadap Kemampuan Berfikir Kritis Mahasiswa. Penelitian dilakukan pada mahasiswa S1 Program Studi Teknik Elektro dan
Peternakan Universitas Islam Lamongan yang menempuh mata kuliah fisika dasar.

\section{METODE}

Rancangan penelitian ini menggunakan desain eksperimen semu faktorial $2 \times 2$, hal ini disebabkan peneliti tidak memungkinkan untuk mengontrol semua variabel yang diduga ikut mempengaruhi perlakuan dan dampak perlakuan terhadap kemampuan berfikir kritis mahasiswa. Rancangan ini dilaksanakan dengan cara melakukan pretest kemampuan berfikir kritis mahasiswa pada kelas eksperimen dan kontrol. Hal ini dilakukan untuk mengetahui tingkat perbedaan kemampuan kedua kelompok penelitian. Setelah itu diberikan perlakuan (treatments) pendekatan pembelajaran Pendekatan Engage, Explore, Explain, Elaborate, dan Evaluate (5E) pada kelas eksperimen dan pendekatan Science, Environment, Technology, and Society (SETS) pada kelas kontrol selama 6 kali pertemuan. Untuk mengoptimalkan penggunaan kedua pendekatan tersebut, saat proses penjelasan dosen dibantu dengan aplikasi media sosial youtube yang menyediakan beragam tayangan dalam bentuk video yang disesuaikan dengan materi yang sedang dipelajari.

Langkah berikutnya melakukan posttest kemampuan berfikir kritis mahasiswa kepada kedua kelompok tersebut. Penelitian ini dilaksanakan pada 30 mahasiswa Program Studi Teknik Elektro dan 28 mahasiswa Program Studi Peternakan Universitas Islam Lamongan dengan menggunakan teknik purposive sampling. Teknik pengumpulan data menggunakan tes tulis dengan empat indikator, yakni interpretasi, analisis, evaluasi, dan inferensi. 
Tabel 1 Deskripsi Indikator Kemampuan Berfikir Kritis Mahasiswa

\begin{tabular}{|c|c|}
\hline $\begin{array}{l}\text { Indikator Kemampuan } \\
\text { Berfikir Kritis Mahasiswa }\end{array}$ & Penjelasan \\
\hline Interpretasi & $\begin{array}{l}\text { Kemampuan yang dimiliki oleh mahasiswa untuk } \\
\text { memahami dan menjelaskan suatu materi ajar, baik } \\
\text { yang disajikan dalam bentuk teks, gambar, maupun } \\
\text { audio-visual yang berhubungan dengan materi di } \\
\text { balik fenomena alam yang terjadi dalam kehidupan } \\
\text { sehari-hari }\end{array}$ \\
\hline Analisis & $\begin{array}{l}\text { Kemampuan mengindentifikasi hubungan, baik } \\
\text { yang dinyatakan secara eksplisit maupun tidak, di } \\
\text { antara pernyataan, pertanyaan, konsep, fakta, bukti, } \\
\text { atau bentuk-bentuk representasi lain dalam upaya } \\
\text { mengenali dan memecahkan suatu masalah }\end{array}$ \\
\hline Evaluasi & $\begin{array}{l}\text { Kemampuan menilai suatu masalah yang sedang } \\
\text { dihadapi secara komprehensif lengkap dengan } \\
\text { pertimbangan situasi dan kondisi yang menyertai } \\
\text { terjadinya masalah tersebut. }\end{array}$ \\
\hline Inferensi & $\begin{array}{l}\text { Kemampuan mengidentifikasi suatu masalah dan } \\
\text { memperoleh unsur-unsur yang diperlukan untuk } \\
\text { menarik kesimpulan yang masuk akal dengan } \\
\text { mempertimbangkan informasi yang relevan }\end{array}$ \\
\hline
\end{tabular}

Hasil tes kemampuan berfikir kritis mahasiswa dengan nilai terendah 0 dan nilai tertinggi 100. Kategori kemampuan berfikir kritis mahasiswa tingkat tinggi yang memiliki rentang nilai 51-100, sedangkan mahasiswa dengan kategori kemampuan berfikir kritis rendah memiliki rentang nilai 0-50. Sedangkan untuk analisis datanya menggunakan analisis deskriptif dan ANOVA dua jalur. Secara detail rancangan penelitian ini tersaji pada tabel 2 di bawah ini.

\section{Tabel 2 Rancangan Penelitian Faktorial 2x2}

\begin{tabular}{lll}
\hline Kemampuan Berfikir Kritis & Pendekatan Pembelajaran $(\mathrm{X})$ & \\
\cline { 2 - 3 } Mahasiswa $(\mathrm{Y})$ & $5 \mathrm{E}\left(\mathrm{X}_{1}\right)$ & SETS $\left(\mathrm{X}_{2}\right)$ \\
\hline Tinggi $\left(\mathrm{Y}_{1}\right)$ & $\mathrm{X}_{1} \mathrm{Y}_{1}$ & $\mathrm{X}_{2} \mathrm{Y}_{1}$ \\
\hline Rendah $\left(\mathrm{Y}_{2}\right)$ & $\mathrm{X}_{1} \mathrm{Y}_{2}$ & $\mathrm{X}_{2} \mathrm{Y}_{2}$ \\
\hline
\end{tabular}

Keterangan :

X1 : Perlakuan pembelajaran dengan pendekatan 5E

X2 : Perlakuan pembelajaran dengan pendekatan SETS berbantu aplikasi media sosial

Y1 : Kelompok mahasiswa yang memiliki kemampuan berfikir kritis tinggi

Y2 : Kelompok mahasiswa yang memiliki kemampuan berfikir kritis rendah
X1Y1 : kelompok mahasiswa yang dibelajarkan dengan pendekatan 5E dengan memiliki kemampuan berfikir kritis tinggi.

X2Y1 : kelompok mahasiswa yang dibelajarkan dengan pendekatan SETS berbantu aplikasi media sosial dengan memiliki kemampuan berfikir kritis tinggi. 
X1Y2 : kelompok mahasiswa yang dibelajarkan dengan pendekatan 5E berbantu aplikasi media sosial dengan memiliki kemampuan berfikir kritis rendah.

X2Y2 : kelompok mahasiswa yang dibelajarkan dengan pendekatan SETS berbantu aplikasi media sosial dengan memiliki kemampuan berfikir kritis rendah.

\section{HASIL DAN PEMBAHASAN \\ Kemampuan Berfikir Kritis Awal Mahasiswa}

Sebelum mahasiswa diberikan pembelajaran dengan menggunakan pendekatan SETS dan 5E dengan pemanfaatan media sosial youtube, kedua kelompok mahasiswa tersebut diberikan pretest terlebih dahulu. Hal ini untuk mengetahui tingkat kemampuan awal berfikir kritis mahasiswa kedua kelas tersebut. Hal ini untuk memastikan bahwa kedua kelompok tersebut tidak memiliki perbedaan yang signifikan berkaitan dengan kemampuan berfikir kritis mereka sebelum diberikan perlakuan pembelajaran, baik dengan menggunakan pendekatan 5E maupun dengan pendekatan SETS.

Berdasarkan hasil analisis statistik diketahui bahwa kemampuan awal berfikir kritis mahasiswa antara kelas eksperimen dan kelas kontrol tidak ada perbedaan yang signifikan. Hal ini didasarkan pada hasil perhitungan nilai pretest dengan menggunakan uji $\mathrm{t}$ ( $\mathrm{t}$-test) diperoleh hasil bahwa t hitung $=0,737$ $<\mathrm{t}$ tabel $=1.955$ pada taraf signifikan $0,464>0,05$. Berdasarkan tidak adanya perbedaan kemampuan berfikir kritis pada kedua kelompok mahasiswa tersebut, sehingga layak untuk diberikan perlakuan dengan pendekatan $5 \mathrm{E}$ untuk kelas eksperimen dan pendekatan SETS untuk kelas kontrol. Secara detail tidak adanya perbedaan kemampuan yang signifikan antara kedua kelompok mahasiswa tersebut bisa dilihat pada hasil analisis pada tabel 3 di bawah ini.

Tabel 3 Hasil Analisis Data Nilai Pretest Kemampuan Berfikir Kritis Mahasiswa

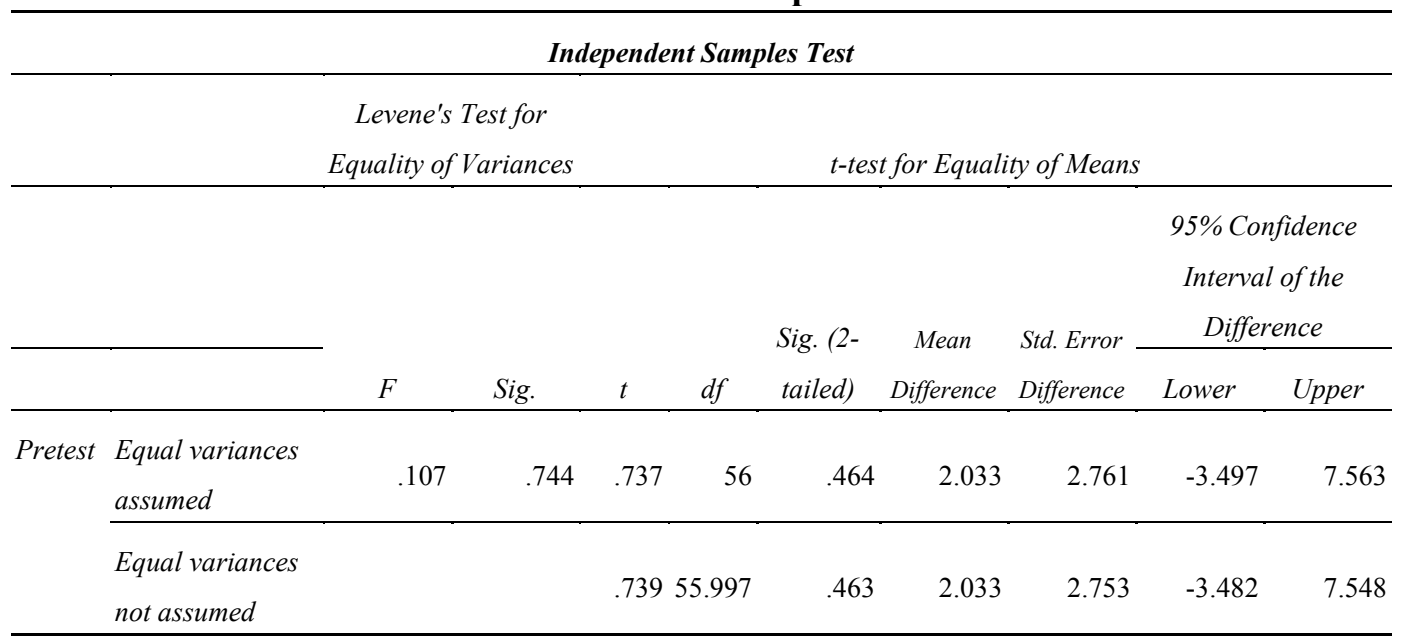


Berdasarkan hasil kajian terhadap nilai pretest tersebut yang dapat disimpulkan bahwa kemampuan awal pada kedua kelompok tersebut tidak memiliki perbedaan yang signifikan, kemudian masing-masing kelompok tersebut dibelajarkan dengan menggunakan pendekatan 5E untuk mahasiswa pada kelas eksperimen, dan pendekatan SETS untuk kelas kontrol. Setelah diberikan perlakuan, maka kedua kelompok mahasiswa tersebut diberikan posttest.

\section{Analisis Kemampuan Berfikir Kritis Mahasiswa setelah Pembelajaran}

Kedua data yang berasal dari nilai posttes kemampuan berfikir kritis mahasiswa baik kelompok mahasiswa yang diberikan pembelajaran dengan pendekatan 5E maupun pendekatan SETS berdistribusi normal, hal ini berdasarkan uji Lilliefors Significance Correction dari Kolmogorof-Smirnov pada kedua kelompok data tersebut memiliki nilai signifikansi (sig.) lebih dari 0,05. Pada kelas eksperimen nilai signifikansinya sebesar 0,200 dan pada kelas kontrol nilai signifikasi (sig.) adalah 0,166 . Selain itu, data pada kedua kelompok tersebut juga homogen yang dibuktikan dengan nilai signifikansi sebesar 0,545.
Hasil analisis deskriptif dengan menggunakan ANOVA dua jalur pada hasil nilai posttest yang dilakukan pada kedua kelompok setelah memperoleh perlakuan pembelajaran baik dengan pendekatan 5E untuk kelas eksperimen maupun pendekatan SETS untuk kelas kontrol menunjukkan hasil peningkatan yang berbeda. Kecenderungan perbedaan peningkatan kemampuan berfikir kritis tersebut dapat diketahui dan sekaligus dilihat pada skor rata-rata yang diperoleh antara kedua kelompok tersebut. Peningkatan nilai rata-rata mahasiswa tersebut juga terjadi baik mahasiswa yang memiliki kemampuan berfikir kritis tinggi maupun mahasiswa yang memiliki kemampuan berfikir kritis rendah.

Nilai rata-rata kemampuan berfikir kritis mahasiswa yang diberikan pembelajaran dengan menggunakan pendekatan 5E adalah sebesar 73.11 dengan standar deviasi 9.339. Sedangkan nilai rata-rata kemampuan berfikir kritis mahasiswa yang diberikan pembelajaran dengan pendekatan SETS memperoleh nilai rata-ratanya sebesar 61.90 dengan standar deviasi 10.908. Untuk lebih jelasnya perbedaan nilai rata-rata antara kedua kelompok mahasiswa tersebut bisa dilihat pada tabel 4 di bawah ini.

Tabel 4 Hasil Analisis Statistik Deskriptif Data Nilai Posttest Kedua Kelompok

\begin{tabular}{lccc}
\hline Instructional_Approach & Mean & Std. Deviation & $N$ \\
\hline 5E Approach & 73.11 & 9.339 & 28 \\
SETS Approach & 61.90 & 10.908 & 30 \\
Total & 67.31 & 11.566 & 58 \\
\hline
\end{tabular}

Abdul Ghofur, Nahdia Rupawanti Basuki Raharjo, Peningkatan Kemampuan Berfikir Kritis Mahasiswa Melalui Pendekatan 5E dan SETS Berbantu Aplikasi Media Sosial 
Kemampuan berfikir kritis kemampuan berfikir kritisnya adalah 57 mahasiswa antara kelas eksperimen dan dan nilai tertingginya adalah 90. Adapun kelas kontrol memiliki perbedaan yang untuk kelas kontrol, nilai terendahnya signifikan. Pada kelas eksperimen yang adalah 44 dan nilai tertingginya adalah dibelajarkan dengan menggunakan 85. pendekatan 5E nilai terendah

Tabel 5 Perbandingan Persentase Kemampuan Berfikir Kritis Mahasiswa Antara Kelas Eksperimen Dan Kelas Kontrol

Kemampuan berfikir kritis Kelompok Kemampuan berfikir kritis Kelompok Mahasiswa yang dibelajarkan dengan Mahasiswa yang dibelajarkan dengan Pendekatan 5E berbantu aplikasi media Pendekatan SETS berbantu aplikasi media sosial

\begin{tabular}{crcrrrrr}
\hline Pretest & & Posttest & \multicolumn{3}{c}{ Pretest } & \multicolumn{2}{c}{ Posttest } \\
\hline Tinggi & Rendah & Tinggi & Rendah & Tinggi & Rendah & Tinggi & Rendah \\
\hline $79 \%$ & $21 \%$ & $100 \%$ & $0 \%$ & $77 \%$ & $23 \%$ & $90 \%$ & $10 \%$ \\
\hline
\end{tabular}

Pengaruh Pendekatan Pembelajaran dengan pendekatan 5E dengan kelompok berbantu Media Sosial terhadap mahasiswa yang dibelajarkan dengan Kemampuan Berfikir Kritis

Berdasarkan hasil analisis dengan ANOVA dua jalur menunjukkan bahwa terdapat pengaruh yang signifikan kemampuan berfikir kritis antara pendekatan SETS. Hal itu ditunjukkan dengan nilai $\mathrm{F}$ hitung sebesar 17.547 dengan nilai signifikansi sebesar 0.000 . Untuk lebih jelasnya bisa dilihat pada tabel 6 di bawah ini kelompok mahasiswa yang dibelajarkan

\section{Tabel 6. Hasil Analisis Data Pengaruh Pendekatan Pembelajaran Terhadap} Kemampuan Berfikir Kritis Mahasiswa Dengan Anova Dua Jalur.

Tests of Between-Subjects Effects

\begin{tabular}{lccccc}
\hline Dependent Variable:Posttest & \multicolumn{1}{l}{} & & & \\
\hline & $\begin{array}{c}\text { Type III Sum of } \\
\text { Squares }\end{array}$ & $d f$ & Mean Square & $F$ & Sig. \\
\hline Source & $1819.035^{\mathrm{a}}$ & 1 & 1819.035 & 17.547 & .000 \\
\hline Corrected Model & 263976.208 & 1 & 263976.208 & $2.546 \mathrm{E} 3$ & .000 \\
\hline Intercept & 1819.035 & 1 & 1819.035 & 17.547 & .000 \\
\hline Instructional_Approach & 5805.379 & 56 & 103.667 & & \\
\hline Error & 270404.000 & 58 & & & \\
\hline Total & 7624.414 & 57 & & & \\
\hline Corrected Total & & & & & \\
\hline
\end{tabular}

a. $\mathrm{R}$ Squared $=.239($ Adjusted R Squared $=.225)$

Berdasarkan hasil analisis statistik

yang dibelajarkan dengan pendekatan di atas diketahui bahwa ada pengaruh yang signifikan kemampuan berfikir mahasiswa antara kelompok mahasiswa $5 \mathrm{E}$ dan kelompok mahasiswa yang dibelajarkan dengan pendekatan SETS. Pada dasarnya ada peningkatan nilai 
kemampuan berfikir kritis pada kedua kelompok mahasiswa tersebut jika dibandingkan dengan kemampuan awal mereka. Namun hasil analisis deskriptif sebagaimana tabel 4 di atas menunjukkan bahwa mahasiswa yang dibelajarkan dengan pendekatan $5 \mathrm{E}$ lebih tinggi nilai rata-rata kemampuan berfikir kritisnya jika dibandingkan nilai rata-rata mahasiswa yang dibelajarkan dengan pendekatan SETS.

Secara teknis pembelajaran kedua pendekatan tersebut telah menunjukkan efektifitasnya dalam upaya meningkatkan kemampuan berfikir kritis mahasiswa pada mata kuliah fisika dasar. Namun dalam implementasinya aktivitas pembelajaran dengan menggunakan pendekatan $5 \mathrm{E}$ dirasa lebih optimal sesuai dengan indikator ketercapaian kemampuan berfikir kritis mahasiswa. Menurut kajian Gazali, dkk (2015) bahwa pendekatan pembelajaran $5 \mathrm{E}$ dapat mengembangkan keterampilan proses sains dan kemampuan berpikir kritis melalui lima tahapan pembelajaran. Hal ini disebabkan tahapan pembelajaran dalam pendekatan $5 \mathrm{E}$ bisa lebih efektif dan sistematis diterapkan dalam proses pembelajaran. Menurut Bybee (2006) bahwa pada fase engage, dosen membantu mahasiswa untuk menggali pengetahuan awal mereka dan mengungkap miskonsepsi terhadap topik yang akan dipelajari. Pada fase explore (mengeksplorasi), mahasiswa diberi kesempatan untuk bereksplorasi secara fisik dan mental terhadap masalah yang dibahas sehingga mahasiswa memperoleh suatu konsep baru, proses belajar dan keterampilan. Pada fase explain, mahasiswa menjelaskan konsep baru yang diperoleh pada fase eksplorasi. Pada fase elaborate, siswa dilibatkan pada suatu diskusi kelompok yang membahas suatu situasi atau permasalahan baru sehingga siswa dapat menerapkan konsep yang telah ditemukan sebelumnya. Pada fase evaluate, siswa diajak untuk mengingat kembali kegiatan yang telah dilakukan selama pembelajaran berlangsung.

Sedangkan pada kelas kontrol yang dibelajarkan dengan pendekatan SETS juga mengalami peningkatan kemampuan berfikir mahasiswa jika dibandingkan dengan kemampuan awal mereka. Namun pendekatan ini lebih menekankan pada pembelajaran aplikatif berdasarkan perkembangan sains, lingkungan, teknologi dan sosial yang dimungkin membutuhkan waktu yang lebih lama untuk bisa memahami secara komprehensif. Menurut Binadja (2002), pendekatan SETS memiliki tujuan membantu peserta didik agar dapat menjelaskan tentang proses sains yang melatarbelakangi fenomena alam, perkembangan sains dan teknologi, serta bagaimana perkembangan sains serta teknologi mempengaruhi lingkungan dan masyarakat. Pendekatan pembelajaran ini mengedepankan proses pembelajaran berbasis peserta didik, learning by doing, mengembangkan kepekaan sosial, membangun dan mengembangkan sikap kritis dan kolaboratif. Aktivitas pembelajaran yang tergolong singkat menjadi salah satu penyebab kemungkinan hasil pembelajaran kurang bisa lebih optimal.

Selaras dengan pendapat tersebut, menurut Mulyasa (2004) bahwa pembelajaran bisa dikatakan berhasil dan berkualitas apabila sebagian besar peserta didik terlibat secara aktif, baik fisik, mental maupun sosial dalam pembelajaran. Selain itu, Sudjana (2012) mengemukakan bahwa salah satu ciri 
pengajaran yang berhasil diantaranya dilihat dari kadar kegiatan belajar siswa. Makin tinggi kadar belajar siswa, makin tinggi peluang berhasilnya pengajaran.

Penggunaan aplikasi media sosial youtube sangat membantu dalam penerapan kedua pendekatan tersebut untuk meningkatkan kemampuan berfikir kritis mahasiswa. Media aplikasi youtube yang menyediakan beragam tayangan lebihbisamembuatmateriyang disampaikan terlihat konkrit, karena bisa langsung dilihat dan diamati yang kemudian bisa dikritisi oleh mahasiswa. Hal ini sangat membantu dosen dalam mengaplikasikan kedua pendekatan tersebut. Pemanfaatan media sosial youtube yang berbentuk video relatif banyak kontennya mampu menarik respon mahasiswa untuk berperan aktif dalam forum pembelajaran. Mahasiswa cenderung mampu dengan mudah menelaah materi melalui beragam video yang tersedia di media sosial youtube yang diberikan oleh dosen dengan menggunakan pendekatan SETS dan 5E. Hal ini juga relevan dengan hasil kajian Kustandi dan Bambang (2013) yang menyatakan beragam keuntungan menggunakan media dalam bentuk video untuk aktivitas pembelajaran, diantaranya: 1) Video dapat melengkapi pengalamanpengalaman dasar peserta didik ketika mereka berdiskusi, membaca, dan praktik. 2) Video dapat menunjukan objek secara normal yang tidak dapat dilihat dan diamati lewat penjelasan maupun gambar. 3) Mendorong dan meningkatkan motivasi peserta didik serta menanamkan sikap dan segi afektif lainnya. 4) Video mengandung nilai-nilai positif yang dapat mengundang pemikiran dan pembahasan dalam kelompok. 5) Video dapat menyajikan peristiwa kepada kelompok besar atau kelompok kecil dan kelompok yang heterogen atau perorangan. Pemanfaatan media yang sesuai juga dapat meningkatkan tingkat partisipasi peserta didik pada materi yang dipelajari. Hal ini sebagaimana pendapat Ghofur (2018) bahwa pemanfaatan media yang tepat dapat meningkatkan antusiasme peserta didik dalam aktivitas pembelajarannya.

\section{SIMPULAN}

$\begin{array}{ccc}\text { Kedua } & \begin{array}{c}\text { kelompok } \\ \text { sebelum }\end{array} & \begin{array}{r}\text { mahasiswa } \\ \text { diberikan }\end{array}\end{array}$ pembelajaran dengan menggunakan pendekatan SETS dan 5E diberikan pretest terlebih dahulu, dan hasil analisis menunjukkan bahwa tidak adanya perbedaan yang signifikan atau dengan kata lain kemampuan berfikir kritis pada kedua kelompok mahasiswa tersebut relatif sama, sehingga layak untuk diberikan perlakuan dengan pendekatan 5E untuk kelas eksperimen dan pendekatan SETS untuk kelas kontrol. Kedua pendekatan tersebut dibantu juga dengan pemanfaatan media sosial youtube.

Setelah kedua kelompok mahasiswa tersebut enam kali diberikan pembelajaran, kemampuan berfikir kritis mahasiswa antara kelas eksperimen dan kelas kontrol memiliki perbedaan yang signifikan. Pada kelas eksperimen yang dibelajarkan dengan menggunakan pendekatan $5 \mathrm{E}$ nilai rata-rata kemampuan berfikir kritisnya adalah 73.11, sedangkan untuk kelas kontrol yang dibelajarkan dengan pendekatan SETS, nilai rata-ratanya adalah 61.90 .

Berdasarkan hasil analisis dengan ANOVA dua jalur pada data nilai posttest kemampuan berfikir kritis mahasiswa menunjukkan bahwa ada 
pengaruh yang signifikan kemampuan berfikir kritis kelompok mahasiswa, baik yang dibelajarkan dengan pendekatan 5E (Engage, Explore, Explain, Elaborate, dan Evaluate) maupun kelompok mahasiswa yang dibelajarkan dengan pendekatan SETS (Science, Environment, Technology, and Society). Hal itu ditunjukkan dengan nilai $\mathrm{F}$ hitung sebesar 17.547 dengan nilai signifikansi sebesar 0.000. Perbedaan tersebut disebabkan pembelajaran dengan menggunakan pendekatan 5E dirasa lebih optimal sesuai dengan indikator ketercapaian kemampuan berfikir kritis mahasiswa, yakni interpretasi, analisis, evaluasi dan inferensi. Pada hasil penelitian ini juga diketahui bahwa waktu pembelajaran yang tergolong singkat menjadi salah satu penyebab pendekatan SETS belum bisa berdampak pada peningkatan kemampuan berfikir kritis mahasiswa secara optimal. Selain itu, penggunaan aplikasi media sosial dalam bentuk youtube dirasa sangat membantu dosen dalam menerapakan kedua pendekatan tersebut. Media youtube yang berupa ragam video dirasa mampu menjadikan pembahasan materi lebih konkrit sehingga mahasiswa bisa lebih mudah menangkap materi yang sedang dipelajari sesuai dengan tahapan pembalajaran yang dilakukan.

\section{DAFTAR PUSTAKA}

Appamaraka, S., Suksringarm, P. \& Singseewo,A. 2009. Effects of Learning Environment Education Using The 5Es-Learning Cycle Approach With The Metacognitive Moves and The Teacher's Handbook Approach on Learning Achievement, Integrated Science Process Skill and Critical Thinking of High School (Grade 9) Students.

Pakistan Journal of Sosial Sciences, 6(5):287-291.

Barlia, L. 2011. Konstruktivisme dalam Pembelajaran Sains di SD: Tinjauan Epistimologi, Ontologi, dan Keraguan dalam Praksisnya. Bandung: Cakrawala Pendidikan.

Binadja, A. 2002. Hakekat dan tujuan pendidikan SETS dalam kontek kehidupan dan pendidikan yang ada. Makalah Seminar dan Lokakarya Nasional.

Budprom W., Suksringam P., Singsriwo A. 2010. Effects of Learning Environmental Education Using the 5E-Learning Cycle with Multiple Intelligences and Teacher 's Handbook Approaches on Learning Achievement, Basic Science Process Skills and Critical Thinking of Grade Students. Pakistan Journal of Social Sciences,7(3):200-204.

Bybee, W.R., Taylor, J.A., Gardner, A., Scotter, P.V.,Carlson, J.P., Westbrook, A., and Landes, N. 2006. The BSCS 5E Instructional Model: Origins and Effectiviness. Colorado Springs, CO: BSCS, 5:88-98.

Gazali, A. Hidayat, A. \& Yuliati, L. 2015. Efektivitas Modul Siklus Belajar 5E Terhadapa Ketrampilan Proses Sains dan Kemampuan Berpikir Kritis Siswa. Jurnal Pendidikan Sains, 3(1): 10-16.

Ghofur, A. 2018. The Use of Media for Science Teaching in Islamic Schools. Jurnal Pendidikan Edutama, 5 (1): 1-8.

Gunawan \& Liliasari. 2012. Model Virtual Laboratory Fisika Modern untuk meningkatkan Disposisi Berfikir Kritis Calon Guru. 
Cakrawala Pendidikan, 2: 185- National Research Council. 2012. 199.

Ibrahim. 2007. Kecakapan Hidup:

Keterampilan Berpikir Kritis.

Surabaya: Universitas Negeri

Surabaya.

$\mathrm{Ku}$, K. Y. L., Irine, T. Ho, Kit-tai

Hau, \& Eva C. M. Lai. 2014.

Integrating direct and inquirybased instruction in the teaching of critical thinking: an intervention study. Instr. Sci, 42: 251-269.

Kustandi, C. \& Bambang, S. 2013. Media Pembelajaran Manual dan Digital disi Kedua. Bogor: Ghalia Indonesia.

Luthvitasari. Navies, N. M. D. P. \& Linuwih, S. 2012. Implementasi Pembelajaran Fisika Berbasis Proyek terhadap Keterampilan Berfikir Kritis, Berfikir Kreatif dan Kemahiran Generik Sains. Journal of Innovative Science Education, 1 (2): 92-97.

Mayadiana, D. 2005. Pembelajaran dengan Pendekatan Diskursifuntuk Mengembangkan Kemampuan Berpikir Kritis Mahasiswa Calon Guru SD. Tesis pada PPs Universitas Pendidikan Indonesia. Bandung: Tidak diterbitkan.

Mulyasa. 2004. Manajemen Berbasis Sekolah, Konsep, Strategi dan Implementasi. Bandung: PT Remaja Rosda Karya.

Nasution. 2008. Berbagai Pendekatan dalam Proses Belajar Mengajar. Jakarta: Bumi Aksara. A framework for $K-12$ Science Education. Washington, DC: The National Academies Press.

Pradana, S. D. S., Parno \& Handayanto, S. K. 2016. Kemampuan Berfikir Kritis Mahasiswa Tahun Pertama Jurusan Fisika Universitas Negeri Malang. Prosiding Semnas Pendidikan IPA Pascasarjana UM: 462-468

Putra, P. D. A \& Sudarti. 2015. Pengembangan Sistem E-Learning untuk meningkatkan keterampilan berfikir kritis mahasiswa. Jurnal Fisika Indonesia, 19 (55): 45-48

Santyasa, I.W. 2008. Model Pembelajaran Yang Efektif Untuk Meningkatkan Keterampilan Berpikir Kritis (Suatu Persepsi Guru). Jurnal Pendidikan dan Pengajaran Undiksha, 2:219-238.

Seals, M. A. 2010. Teaching students to think critically about science and origins. Cult. Stud of Sci Educ, 5: 251-255

Sudjana, N. 2012. Penelitian Hasil Proses Belajar Mengajar. Bandung: PT Remaja Rosda Karya.

Yamin, M. 2008. Paradigma Pendidikan Konstruktivistik. Jakarta: Gaung Persada Press (GP Press).

Yulistiana. 2015. Penelitian Pembelajaran berbasis SETS (Science, Environment, Technology, and Society) dalam pembelajaran Sains. Jurnal Formatif, 5 (1): 7682.

JINoP (Jurnal Inovasi Pembelajaran),Volume 4, Nomor 2 , November 2018, hal 102-112 